\title{
Using GIS to map the evolution of the Gaeltacht
}

\author{
Emer Ni Bhrádaigh, Stephen McCarron, John Walsh and Patrick Duffy \\ Fiontar, Dublin City University; Department of Geography, National University of \\ Ireland,Maynooth; School of Irish, National University of Ireland, Galway and Department \\ of Geography, National University of Ireland, Maynooth
}

\begin{abstract}
This paper describes the results of using digital mapping techniques (Geographic Information Systems - GIS) to facilitate the translation of historical legislative documents into large-scale (townland level) maps of the Gaeltacht. The boundaries of the Gaeltacht, within the error limits of the digital spatial data, indicate the changing spatial extent of the Gaeltacht from its inception through phases of legislative reform throughout the 20th century. This spatial definition of the Gaeltacht has largely been the basis of protection for the Irish language since independence. Changes in the defining criteria and modification of areas comprising the Gaeltacht have resulted in a discontinuous modern Gaeltacht which lacks definition in any single legislative document. A digital version of the modern Gaeltacht boundary in a GIS readable format will allow its integration with other spatial datasets and gives the administrative region new clarity of definition. This paper does discuss the actual use of Irish in the Gaeltacht.
\end{abstract}

Key index words: Gaeltacht; Geographic Information Systems.

\section{Introduction}

A range of evidence suggests that the Irish language experienced increasing social, economic and regional marginalisation in Ireland throughout the eighteenth and nineteenth centuries (Government of Ireland, 1926). Its area of most intensive use contracted westwards, into predominantly nural districts, where it was spoken increasingly by the poorest classes. At local level, the National Education Act of 1831, the powerful influence of the Catholic church, the pressures of emigration and rural depopulation, and the socially-devastating effects of the Great Famine, fed into a political and social discourse which privileged English speakers and marginalised Irish as an everyday vernacular language. The nineteenth-century cultural revival probably came too late to stop this marginalisation of the language, though Irish and its resurrection became a fundamental icon of the nationalist struggle. However, with the establishment of the Free State in 1922, revival of the language became as important in ideological terms as economic development (Wall, 1969; Ó Murchú, 1985; Lee, 1989; Matthews, 2003).

In order to expedite state support for the language, more accurate definition of the geography of the Irish-speaking population was called for. With a view to outlining the boundaries of 'Irish-speaking districts' in the 1920s, a Garda Siochána survey of household Irish usage was commissioned in 1925 to establish where Irish speaking populations were concentrated (Government of Ireland, 1926:5). The Gaeltacht was defined as a territory in which Irish was spoken as the predominant everyday language. Initially this was on the basis of amalgamated Electoral Divisions (ED), the spatial unit used in the Garda survey of 1925 to structure data collection and aggregation.

Irish Geography, Volume 40(1), 2007, 99-108. 
The establishment of the Gaeltacht was part of a programme of intended language/cultural protection by the new Irish Free State. There had been earlier British Administration precedents for state intervention to address issues of rural poverty and regional underdevelopment in Ireland, best reflected, for example, in the institution of the Congested Districts Board (CDB) in 1891, and its expansion in 1909 (Morrissey, 2001; Breathnach, 2005).

The boundaries of the Gaeltacht, as well as the criteria for defining any area (e.g. percentage of the resident population using Irish as their everyday language), have been changed by legislation and statutory instruments throughout the 20th century. The importance of its spatial definition has also increased throughout this period, and particularly in the last decade. Economic development has created an overlap between urban fringes and the Gaeltacht, resulting in bisection of new residential and industrial areas by its boundary (Walsh et al., 2005).

\section{Gaeltacht spatial units}

The spatial framework which supported the territorial designation of the Gaeltacht was principally comprised of electoral divisions and townlands (with small numbers of Urban Districts). The townland was the smallest unit in Ireland which formed local subdivisions of parishes, baronies and counties. Townlands evolved out of a complex range of small landholding units in medieval Ireland which were fossilised in the plantation surveys of the seventeenth century and were finally accurately mapped by the Ordnance Survey from the 1830 s onward. They were subsequently used to construct EDs within Poor Law Unions for the administration of the poor law in the 1840s. The EDs were composed of groups of townlands whose populations elected members to the Boards of Guardians in the Union workhouses. Thus the territorial units which form the basis of Gaeltacht areas were legacies of the middle ages and earlier nineteenth century administrative reforms (Duffy, 2007:53-63; 97-99). Only the townland, however, has had any local community significance.

\section{Methodology}

The use of Geographic Information Systems (GIS) has developed and expanded greatly in the last decade. INSPIRE, the forthcoming European Union Directive, aims to establish a European Spatial Data Infrastructure within which each state will be obliged to gather, store and make available spatial information in a standardised manner (INSPIRE, 2007). In recent years most county councils have appointed GIS officers and many state bodies use GIS as a tool to organise and visualise data in a spatial context. To this end, Ordnance Survey Ireland provides updated datasets showing current Gaeltacht boundaries in digital format and also catalogues name changes such as those introduced by the Placenames (Ceantair Ghaeltachta) Order of 2004.

It was with a view to examine this modem distribution in the context of previous Gaeltacht definitions that the authors compiled a database of information relating to the current or past Gaeltacht status of over 1,000 townlands and EDs. The data were assembled through the examination of surveys, legislation and statutory instruments published between 1925 and 1982. These documents designated the names of Rural and Urban Districts (RDs and UDs), EDs, and townlands included in the Gaeltacht at these times, or additions or subtractions to the existing Gaeltacht. 
Ordnance Survey Ireland (OSi) digital boundaries for polygons representing townlands and digitised obsolete Urban District wards were used to create the various spatial definitions of 'Gaeltacht territory' at key time slices during this period. As all EDs in the study area are composed of aggregated townlands, and these had a more detailed digital definition available to the authors, the constituent townland boundaries were used to provide ED mapping. This spatial dataset was linked in a GIS to the digital database containing information on which EDs, UDs or townlands were part of the Gaeltacht at any time. The linkage is facilitated by the use of unique codes contained within, and common to both datasets (the OSi's ED_no or tland id fields for EDs and townlands respectively). Additional unique codes were created to link digitised areas with their relevant records. The split nature of the data (a spatial dataset of defined polygon borders and an 'external' database of attribute information) allows maximum flexibility in editing and future modification of one or other dataset, which can occur independently.

Spatial units (townlands, UDs etc) are thus linked to a classification of their status (related to inclusion in the Gaeltacht) at selected times over the study period. This allows for mapping of such attribute information at will (e.g. Gaeltacht survey status of each townland). In due course additional information may be added to the database if desired, and also mapped.

\section{The changing territory of the Gaeltacht}

The Gaeltacht in Ireland refers to areas of seven counties (Donegal, Mayo, Galway, Kerry, Cork, Waterford and Meath) designated in legislation. The Gaeltacht was originally defined by a government commission established in 1925, in a move which saw the new Free State place cultural and linguistic considerations at least on a par with economic issues. Although the Land Commission continued to implement some of the land distribution policies of the former CDB, from 1932 there was greater emphasis on assisting the Irishspeaking parts of the congested districts of the west (most dramatically exemplified in group migrations to county Meath from 1935-1940 (ó Tuathaigh, 1986; Nolan, 1988; Ó Ciosáin, 1993). Various revisions since 1925 have resulted in some large and some small isolated, pockets in seven counties within which Irish is deemed to be the 'community language' (Walsh et al., 2005). There is an acknowledged disparity between the official designation of Gaeltacht areas and the actual vitality of the language within Gaeltacht communities (Coimisiún na Gaeltachta, 2002; Mac Donnacha et al., 2004), perhaps most publicly aired in recent years in the debate on the official name of An Daingean in the Kerry Gaeltacht (Hickey, 2007). Under the Official Languages Act, 2003 and the subsequent Placenames (Ceantair Ghaeltachta) Order, 2004 the sole official name of the town is An Daingean. The 2006 plebiscite overwhelmingly supported the bilingual name Dingle / Daingean Ui Chiis in opposition to the Government's decision two years earlier. It is beyond the scope of this paper to discuss or address the issue of actual language usage throughout the Gaeltacht. The database constructed in this project and presented in this paper provides a foundation for such research. Examples of future research are the mapping of linguistic and other socio-economic data such as those compiled by the Central Statistics Office. Nevertheless this paper deals only with the legislation and not actual Irish language usage. 


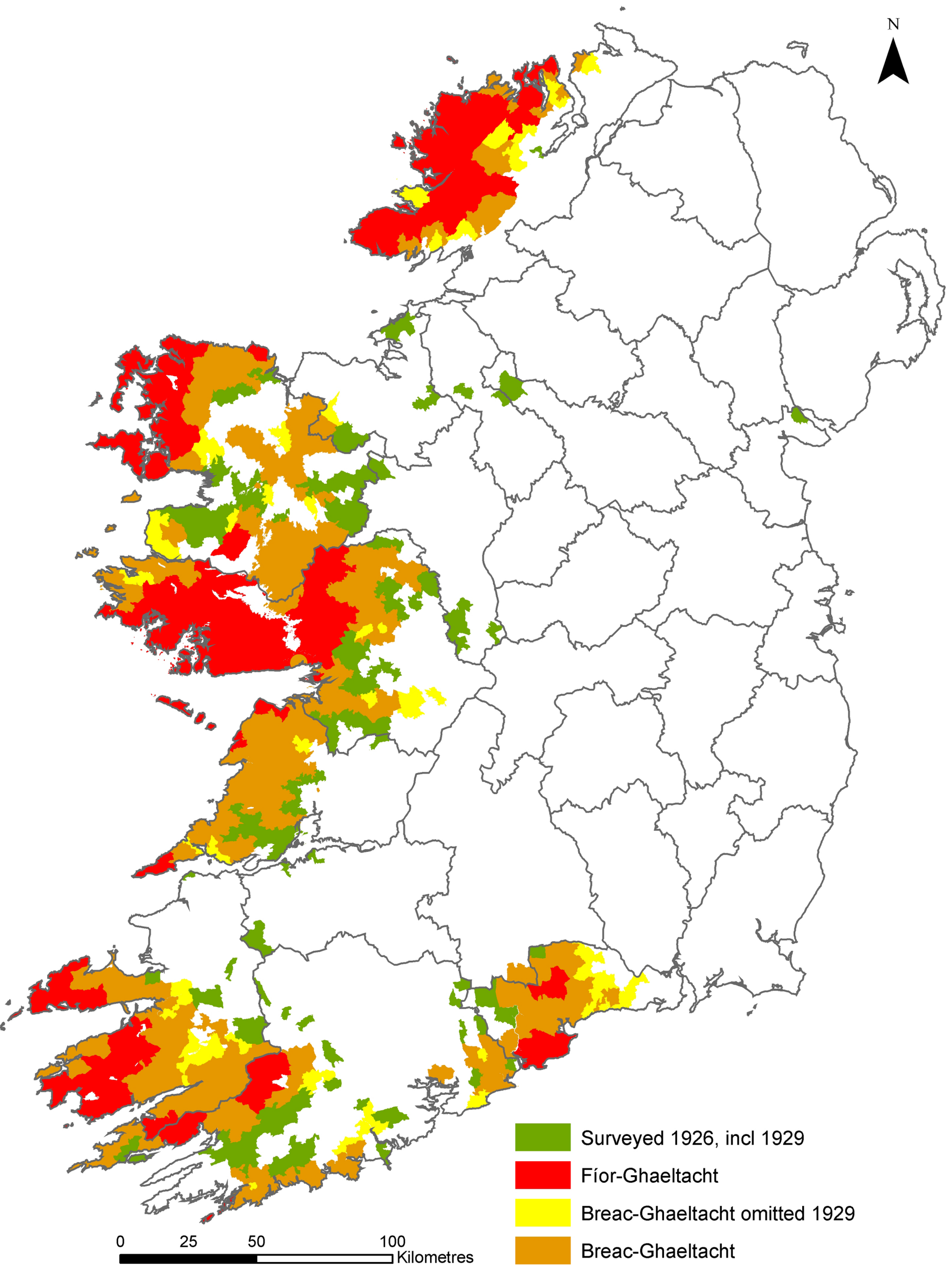

(C) Ordnance Survey Ireland/Government of Ireland Copyright Permit No. MP 002907 
Gaeltacht definition, 1920s

The following is an explanation of the map presented in Figure 1. In 1925, as a prelude to the work of the Gaeltacht Commission, the govemment requested the Garda Siochána to conduct a special enumeration in areas where 'considerable numbers of Irish Speakers might be located' (Government of Ireland, 1926:5). Based on the enumeration, EDs were classified into two categories of Gaeltacht: Fior-Ghaeltacht ('true' Gaeltacht), where a minimum of 80 percent of the population could speak Irish and Breac-Ghaeltacht (partial Gaeltacht), where between 25 and 79 percent could do so. These areas are coloured red and brown respectively in Figure 1. The map illustrates the Fior-Ghaeltacht located in counties Donegal, Mayo, Galway, Kerry, Cork and Waterford with small pockets in County Clare. There were BreacGhaeltacht regions in all of the above counties as well as a small pocket in the south of Tipperary (Government of Ireland, 1926; Walsh, 2002). The Commission proposed 585 EDs for inclusion in the Gaeltacht in a modification of the original definition. Not all EDs designated as Fior-Ghaeltacht, for example, contained Irish-speaking populations of more than 80 per cent, and similarly, not all the Breac-Ghaeltacht EDs reached the 25 per cent threshold (Walsh et al., 2005). The Gaeltacht status (Fior-or Breac-) of each ED, was dictated by the percentage of Irish speakers reported in the enumeration, not according to the category chosen by the Commission (Figure 1).

The first legal definition of the extent of the Gaeltacht was made by the Local Offices and Employments (Gaeltacht) Order, 1928. That Order made no distinction between FiorGhaeltacht and Breac-Ghaeltacht, however, nor were the percentage tbresholds for deciding an area's Gaeltacht status enshrined in the legislation. The Housing (Gaeltacht) Act, 1929 contained another list of EDs designated as Irish-speaking, this time based on the national Census of 1926 (Ó Riagáin, 1997). An appendix in this act designated 660 EDs as "Gaeltacht", an increase of 75 on the decision of the Commission. These additional areas are coloured green in Figure 1. Consequently, by 1929 - for the purposes of housing improvement grants - small numbers of EDs in Counties Cavan, Limerick, Leitrim, Louth and Sligo had been added to the Gaeitacht in addition to those parts of the existing eight Gaeltacht counties. The 1929 Act also removed from the Gaeltacht several EDs which bad been designated as Breac-Ghaeltacht by the Commission. These are coloured yellow on the map. The 1929 Act remained in place until a series of amendments were passed between 1959 and 2001 (Ó Súilleabhain, 2005). Between the 1920s and 1956, modifications to the Gaeltacht were made at ED level.

\section{The Contemporary Gaeltacht}

In 1956, the Gaeltacht was reduced significantly following a major review (Gaeltacht Areas Order, 1956). For the first time, Gaeltacht boundaries were delimited at the townland scale (Figure 2). The review was conducted contemporaneously with the Ministers and Secretaries (Amendment) Act, 1956 which established the first government Department of the Gaeltacht and contained a provision permitting the definition and amendment of Gaeltacht areas as required. For the first time, a distinction was made between EDs which were entirely in the Gaeltacht (coloured beige on the map), and parts of EDs (individually named townlands, coloured red) which were included. 


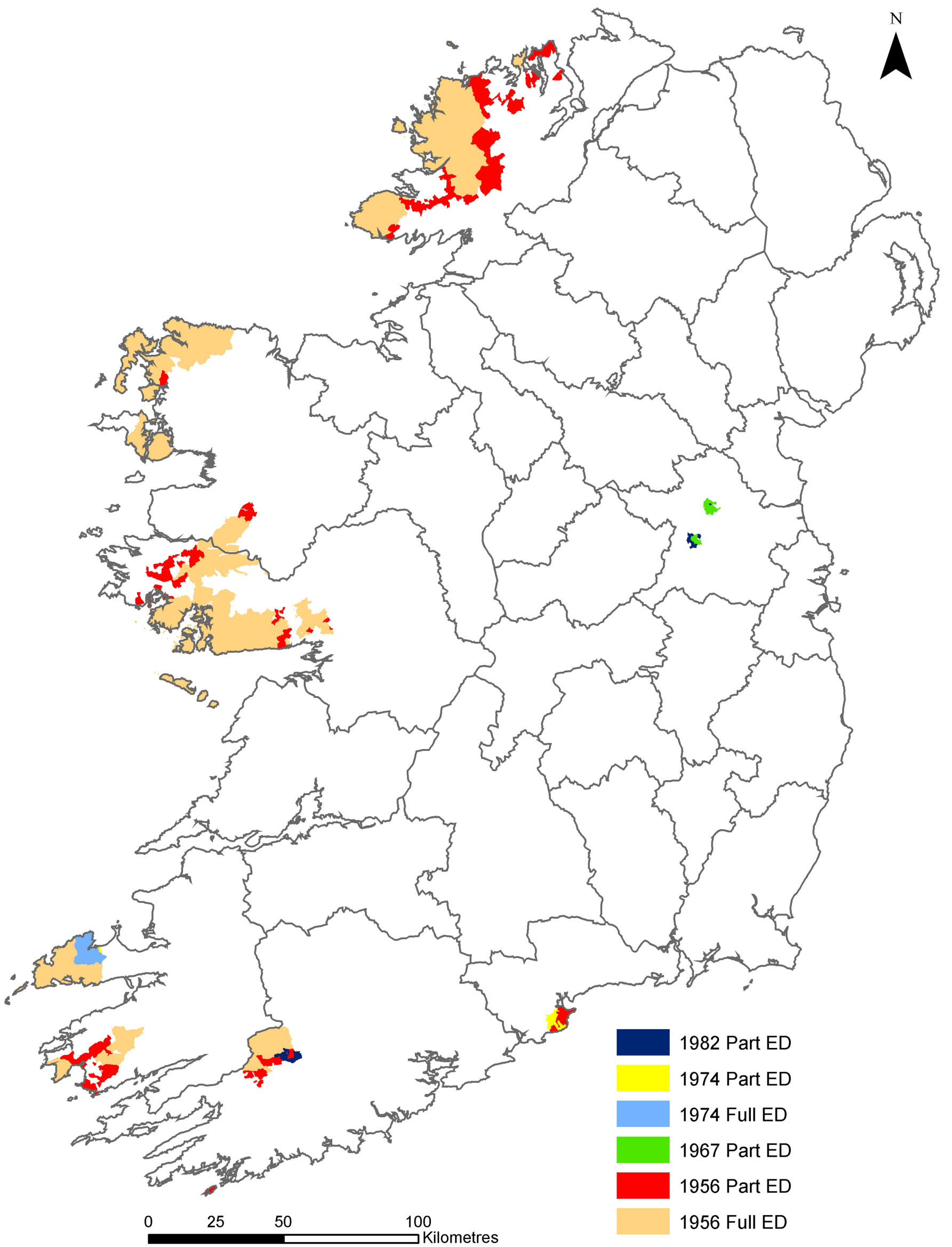

(c) Ordnance Survey Ireland/Government of Ireland Copyright Permit No. MP 002907 
Under the Gaeltacht Areas Order, 1956, only 84 entire EDs and parts of a further 58 in Counties Donegal, Mayo, Galway, Kerry, Cork and Waterford were included in the Gaeltacht. County Clare lost its Gaeltacht status entirely, as did the small area of south Tipperary formerly included, and large swathes of territory were removed from the other six counties. No reference is made in the Order to the distinction between Fior-Ghaeltacht and BreacGhaeltacht and no information is provided about percentage thresholds of speakers required to designate an area as Gaeltacht. Although twenty years had elapsed since the establishment of the first Gaeltacht 'colonies' in County Meath (Whelan et al., 2004) they were not granted Gaeltacht status in this major review.

The 1956 Order has been amended on three occasions. In 1967, following a long campaign by residents of the Gaeltacht settlements in Meath, ten townlands in Rath Caim (Rathcarran) and Baile Ghib (Gibstown) were granted Gaeltacht status. These are coloured light green on the map. In 1974, again as a result of sustained local campaigns, three entire EDs (coloured yellow) and part of a fourth (also coloured yellow) east of An Daingean (Dingle) in County Kerry were added, as were 30 townlands in the Waterford Gaeltacht (coloured yellow), mostly in the parish of An Seanphobal (Oldparish). In 1982, 22 townlands were added to the Múscrai (Muskerry) Gaeltacht in west Cork, along with five more townlands in Meath (coloured indigo on the map).

\section{Discussion}

The Gaeltacht has never been a consolidated, or significantly consolidating, region. Several reviews of Gaeltacht territorial definition have resulted in confusion about the precise extent of the Gaeltacht which has persisted to the present day (Walsh et al., 2005). The need for clarity grows as the territorial definition of the Gaeltacht means an increasingly frequent overlap with modem urban developments (e.g. in the environs of Galway city).

The spatial dimensions of the modem Gaeltacht largely reflect a geographical inertia in its territorial definition, despite successive legislative reviews. Since 1956, some areas have been added but no areas have been removed. Legislation in the 1920s established the system of apportioning state support to those resident in these areas, based on the ability to speak Irish. However, a major sociolinguistic review of the Gaeltacht is expected to be published in 2007 which may lead to further revision of the boundaries and, consequently, eligibility for state support (Department of Community, Rural and Gaeltacht Affairs, 2004). The implications of the boundaries are not restricted to state support for Irish speakers but also apply to industrial and enterprise issues. Since the 1950s, state industrial and enterprise support in the Gaeltacht has been administered through the successive departments responsible for the Gaeltacht rather than those departments responsible for enterprise development (Ni Bhrádaigh, forthcoming).

The use of a spatial definition (ED) also used in other state procedures, such as the. release of Census of Population statistics, also allows the possibility of integrating and analysing the Gaeltacht definition and socio-economic datasets. Some problems arise however in the analysis of the population resident in modern Gaeltacht areas, as amendments since 1956 were made at townland level (i.e. the addition and subtraction of only part-EDs) (Ní Bhrádaigh and McCarron, 2005). Part-EDs comprise a portion of an ED's land area and thus only a proportion of the total ED population as released through the Central Statistics Office's Small Area Population Statistics. Issues of enumerated person's anonymity arise if statistics for spatial areas at sub-ED levels are released. This precludes studies using socio- 
economic statistics for areas of low populations, including, by default, many rural Gaeltacht areas. In addition, data for Industrial Production and Retail Services are only released at County level, thus making it difficult for independent (as distinct from governmentcommissioned) researchers to conduct any rigorous analysis of the Gaeltacht.

In an era of digital mapping technology, it is suggested that a digital representation of the Gaeltacht is the best method of integrating it into modern GIS-based planning and administrative systems. The practice of designating non-contiguous areas continues to date, for example with the areas designated under the CLÁR programme for 890 EDs in rural areas (Department of Community, Rural and Gaeltacht Affairs, 2006). It is ironic that modern technology will perhaps more easily allow the continuance of historically fragmented regions due to these advances in mapping techniques.

\section{Acknowledgements}

The authors wish to acknowledge the assistance of Pádraig Ó hAoláin, Chief Executive of Údarás na Gaeltachta and of Breanndán Ó Súilleabháin of the Department of Community, Rural and Gaeltacht Affairs. The authors also acknowledge the financial support of the Irish Research Council for the Humanities and Social Sciences for the conducting of this research, and of Udarás na Gaeltachta in publishing the colour maps.

\section{References}

BREATHNACH, C. (2005) The congested districts board of Ireland, 1891-1923: poverty and development in the West of Ireland. Dublin: Four Courts Press.

COIMISIÚN NA GAELTACHTA (2002) Tuarascáil/Report. Dublin: Department of Arts, Heritage, Gaeltacht and the Islands.

DEPARTMENT OF COMMUNITY, RURAL AND GAELTACHT AFFAIRS (2004) 'Conradh i ndáil le Staidéar Teangeolaíoch ar Úsáid na Gaeilge sa Ghaeltacht Fógraithe ag Ó Cuív' Press release, 31 January 2004. http://www.pobail.ie/ie/preaseisiuinti/2004_Eanair/htmltext,4017,ie,html (read 25 February 2005).

DEPARTMENT OF COMMUNITY, RURAL AND GAELTACHT AFFAIRS (2006) Description of

CLAR. http://www.pobail ie/en/RAPIDandCLR/CLR/ (read 8 February 2006)

DUFFY, P.J. (2007) Exploring the history and heritage of Irish landscapes. Dublin: Four Courts Press.

GOVERNMENT OF IRELAND (1926) Gaeltacht commission: report. Dublin: Stationery Office. HICKEY, D. (2007) Tourism fears as Dingle name erased from signs, Irish Examiner, 11 January. INSPIRE (2007) The INfrastructure for SPatial InfoRmation in Europe. http://inspire.jrc.it/ Read 24 January 2007.

LEE, J.J. (1989) Ireland 1912-1985: politics and society. Cambridge: Cambridge University Press, 658-674.

MATTHEWS, P.J. (2003) Revival: the Abbey Theatre, Sinn Fein, the Gaelic League and the Co-operative Movement. Cork: Cork University Press. 
MORRISSEY, J. (ed.) (2001) On the verge of want, Dublin: Crannog Books.

MAC DONNACHA, S., NÍ CHUALȦIN, F., Ní SHÉAGHDHA, A. \& Ní MHAINÍN, T, (2004) Staid reatha na scoileanna Gaeltachta 2004: tuarascáil don chomhairle um oideachas Gaeltachta agus Gaelscolaiochta. Dublin: COGG.

NI BHRÁDAIGH, E. (fortheoming) Gaeltacht entrepreneurship: an opportunity for integrated development, yet peripheral in many ways, Irish Joumal of Management Special Entrepreneurship Issue.

NÍ BHRÁDAIGH, E. and MCCARRON, S.G. (2005) Spatial analysis of rural enterprise in Ireland possibilities and limitations. Paper delivered at Irish Academy of Management conference, GMIT, 8 and 9 September.

NOLAN, W. (1988) New farms and fields: migration policies of state land agencies 1891-1980, In: Smyth W. and Whelan, K. (eds) Common ground: essays on the historical geography of Ireland. Cork: Cork University Press, 296-319.

Ó CIOSÁIN, É. (1993) An t-Éireannach 1934-1937: páipéar sóisialach Gaeltachta. Dublin: An Clóchomhar.

Ó MURCHÚ, M. (1985) The Irish language, Dublin: Government of Ireland.

Ó RIAGÁIN, P. (1997) The Galway Gaeltacht 1926-1981: a socio-linguistic study of continuity and change, In: Moran, G and Gillespie, R. (eds) Galway: history and society. Dublin: Geography Publications, $651-680$.

Ó TUATHAIGH, G (1986) Aistriú pobail Ghaeltachta go háiteanna eile in Ėirinn: Cúlra an pholasaí. In: Ó Conghaile, M. (ed.) Gaeltacht Ráth Cairn: léachtai comórtha. Béal an Daingin: Cló IarChonnachta.

Ó SÚILLEABHȦIN, B. (2005) personal communication with John Walsh.

WALL, M. (1969) The decline of the Irish language, In: Ó Cuiv, B. (ed.) A view of the Irish language, Dublin: The Stationery Office, 81-91.

WALSH, J. (2002) Dichoimisiúnt teanga: coimisiun na Gaeltachta 1926. Dublin: Cois Life. WALSH, J., MCCARRON, S.G and NÍ BHRÁDAIGH, E. (2005) Mapping the Gaeltacht: towards a geographical definition of the Irish-speaking districts, Administration (53)1, 16-37.

WHELAN, K., NOLAN, W. and DUFFY, P.J. (2004) State-sponsored migrations to the east midlands in the twentieth-century, In: Duffy, P.J. (ed.) To and from Ireland: planned migration schemes c1600-2000. Dublin: Geography Publications, 175-196.

Gaeltacht Areas Order, 1956

Gaeltacht Areas Order, 1967

Gaeltacht Areas Order, 1974

Gaeltacht Areas Order, 1982

Housing (Gaeltacht) Act, 1929

Housing (Gaeltacht) Amendment Act, 2001 
Irish Land Act, 1909

Land Purchase (Ireland) Act, 1891

Local Offices and Employments (Gaeltacht) Order, 1928

Ministers and Secretaries (Amendment) Act, 1956

National Education Act, 1831

Official Languages Act, 2003

Placenames (Ceantair Ghaeltachta) Order, 2004 